\title{
Luminaries in Shadows: Women in Conrad's Heart of Darkness
}

Dr. Shreeja Tripathi Sharma

Assistant Professor

Department of English

Institute for Excellence in Higher Education

Bhopal, M.P, India

shreeja.sharma@gmail.com

\begin{abstract}
Joseph Conrad's novella Heart of Darkness is a popular modernist work which has often been implored for racist undercurrents. The characterisation of women in the novella remains frail and severely restricted. However, the seemingly mute and insignificant figures of the narrative are an 'absent presence' which shapes and directs Marlow's spiritual quest into the "heart of darkness". The novella is a text which captures the feminist ethos rising in the contemporary British society as an invisibly powerful undercurrent.

Keywords: Joseph Conrad, Heart of Darkness, Women, Feminism, Gender Roles

Joseph Conrad wrote his novella, Heart of Darkness while the perception of women and their role in society was witnessing a transformation. The issues of autonomy of women and gender roles were being shaped by movements like the women's suffrage. Despite the dawn of societal changes in the ever-evolving identity of women, it is apparent that Conrad assigned little scope for women characters and their development in his work and cast them aside, into a fanciful and much restricted plane of existence, far away from that of men. However, there is more than what meets the eye and the feminine identity runs as a powerful shaping influence, which is an 'absent- presence' in the novella.
\end{abstract}


Marlow consistently depicts women characters as weak, deluded and naïve. The exploration in the novella narrated through the protagonist, seems to take place in a man's world, and has scanty, weak women characters, with a severely restricted narrative role. They are depicted as fanciful figures stuck in an idealistic universe of their own creation.

The narrator in the novella, towards the very beginning reads, "It's queer how out of touch with truth women are..." (Conrad, 10). Conrad builds the introductory stage which delineates the scope for women in the narrative with his opening statement. The novel through its course, reiterates Marlow's view of women as being out of touch with the realities of the world. However, the women characters seem to speak through their silence.

The protagonist of the novel Marlow is hired by a trading company to sail up a river in Congo. The novella begins with Marlow narrating a story of his own experience to his friends, which is apparently a journey of his metaphorical spiritual quest. The narrative continues with critical undertones of imperialism and colonialism. Marlow soon realises that the ideals of imperial grandiose of civilising and helping the so-called 'savages' are in reality wrapped in hypocrisy and the missionary intentions of developmental promise of the imperial authorities are not free of exploitative agenda.

The intention of the imperial authorities behind Marlow's expedition to Africa was extraction of the precious ivory and natural resources, rather than the professed ideals of civilisation. As Marlowe matures from his naïve disposition, he suffers psychologically on a mental plane. In contrast to Marlowe, the much-eulogized Kurtz who apparently seems to be an ideal leader, fails to understand his own self and is severely lacking in the inner strength to confront his unknown self. Marlow rescues him in the end of the story but Kurtz dies on their way back. 
In the end of the novel, Marlow visits Kurtz's fiancée, Intended to give her letters and personal papers. It is clear that she loves a fanciful image of the eulogized hero Kurtz and is oblivious of the actual man, an apparently brutal and frail person.

However, though he hates falsity, Marlow, chooses to cover Kurtz's façade of falsity as probably he wants to keep Intended secure and sealed in her world of oblivion. He doesn't reveal Kurtz' last words: "The horror! The horror!" (Conrad, 91) to her and says instead that he had taken her name.

The novella thus ends on a note with Intended remaining confined to the zone of imagination and falsity. Marlow, who hates hypocrisy, chooses not to lift the veil of illusion so as not to shatter her emotionally. Intended's perception of her lover was unreal as she saw Kurtz the way she perceived fit, her exposure to reality would have shattered her beliefs. Marlow apparently thinks it fit to keep her happily shielded behind the mask of illusion.

However, even though the women characters appear meek and mute, they seem to speak through their silence. The portrayal of women reflects the status of contemporary women and raises feministic questions about their autonomy. Even though the women appear merely as few, minor characters in the narrative, they have a deeper symbolic significance. This can be illustrated by the following women characters of the story.

Firstly, Marlow undertakes the journey because of his aunt. She regards Marlow's appointment to the Company as an opportunity to spread the glory of the West world towards the more savage and uncultivated parts of the world. She feels Marlow will be "weaning those ignorant millions (the Africans) from their horrid ways." She believes he will bring truth and light to a 'dark place in the world'.

The women who are seemingly insignificant characters, seem to control and exert influence over men. Marlow says about his aunt, "It's queer how out of touch with truth 
women are. They live in a world of their own ...". This sentiment about women is played out in Marlow's attitude toward his aunt as well as in his later meeting with Kurtz's fiancée. This seems to be a point of view shared by Kurtz who says regarding women, "We must help them to stay in that beautiful world of their own, lest ours gets worse."

Secondly, when Marlow arrives at the offices of the Company, he meets two women, "one fat and the other slim", "who sit knitting with black wool". He views them as "guarding the door of Darkness." While these women appear only briefly and, on the surface, seem to be trivial. Yet they are important characters with respect to their symbolic meaning.

The two women correspond to the mythological Fates who spin, measure, and cut the thread of life. It is in the offices of the Company that Marlow's life is being measured by Fate, as he begins his journey into the heart of Darkness.

Thirdly, Kurtz's enigmatic African mistress, “a wild and gorgeous apparition of a women", undoubtedly casts a strong influence over Kurtz. She is also able to create fear in others, which is evident with the discussion she has with the Russian. Neither Marlow nor the reader is able to learn anything about her since she does not speak. Her silence seems to reinforce the enigmatic nature of women, which is difficult to decipher. However, even though silent and subservient, she is a significant influence in Kurtz's life.

Fourthly, Intended is Kurtz's fiancée whom Marlow goes to visit her after his death. She seems to exemplify Marlow's earlier statement that women live in their own world. She is naïve to the extreme about Kurtz and about his activities in Africa. Her version of her fiancé has little to do with the reality that Marlow has witnessed, yet he cannot bring himself to shatter her illusions. In the end, he decides to lie to her and tell her that the last thing Kurtz said before he died was her name. Marlow says that to have told her the truth "would have been too dark - too dark altogether ...”. Marlow seems to have decided to heed Kurtz's request that women have their own "beautiful world" that must not be sullied. 
Further, the women characters in Heart of Darkness are significant on account of two significant points. They symbolically reflect the oppression and influence of imperial colonies by the analogy of feminine subjugation. And, they hint at the brutal imperial intentions of plundering the rich bounty of the so-called savage countries, on the missionary pretext of civilising them and raises question towards the treatment of women and imperial colonies.

Marlow, embarks on a journey which turns out to be more profound and metaphorical rather than actual. As Marlow moves towards the dark inner station of Congo, he also journeys his own dark inner world. The women in the quest narrative of self-discovery seem like unexplored dimensions of Marlow's transforming perception.

The women in Heart of Darkness, appear as minor characters insignificant characters who seemingly have little role to play in the narrative. Yet they have a deeper symbolic significance. Though apparently powerless, they do exert a substantial influence over men. The narrative seemingly establishes an analogy between men and imperial powers on one hand and between women and colonies on the other raises significant questions towards the treatment of both. The silence of women in the narrative confines them to unexplored dark spaces, but their powerful shadow, illuminates and charters the action in the novel, like the pages of destiny herself, revealed bit by bit. 


\section{Bibliography}

Brantlinger, Patrick. "Heart of Darkness: Anti-Imperialism, Racism, orImpressionism?"

Fictions of Empire. ed. John Kucich. Boston: Houghton- Mifflin, 2003

Conrad, Joseph. Heart of Darkness. New Zealand: The Floating Press, 2008.

Watt, Ian. "Heart of Darkness and Nineteenth-Century Thought." Joseph Conrad'sHeart of Darkness. Ed. Harold Bloom. New York: Chelsea House Publishers, 1987. 